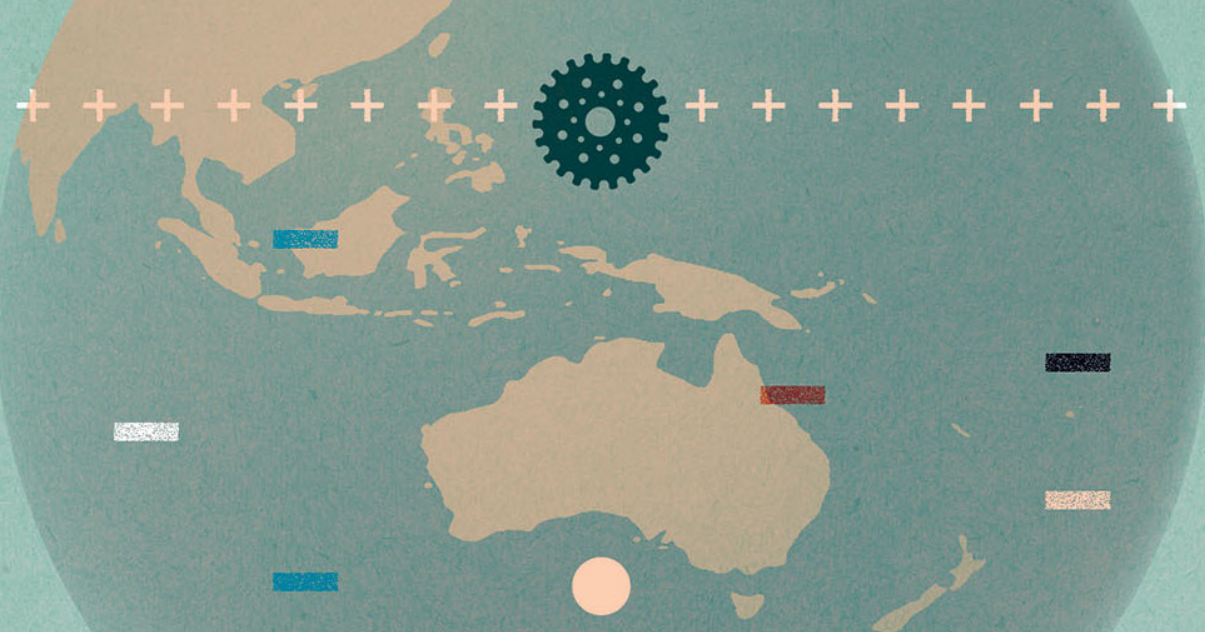

$++t+t+t+t+t+t+t+t+$

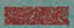

$+t+t+t+t+t+t+t+t+t$

$++t+t+t+t+t+t+t+t+$

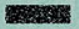

$++t+t+t+t+t+t+t+t+$ maxe

$+t+t+t+t+t+t+t+t+t$

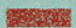

$+++t+t+t+t+t+t+t+t$

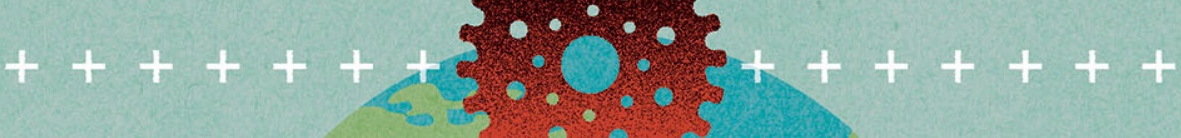

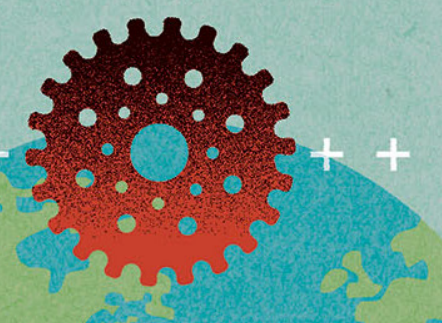




\title{
O Estado desenvolvimentista: vivo ou morto?
}

\author{
The Developmental State: Dead or Alive?
}

\author{
Robert Wade*
}

\begin{abstract}
Resumo
Antes da década de 1980, a principal receita dada pelo Ocidente aos países em desenvolvimento para acompanhá-los atribuía ao Estado um papel de liderança sobre o mercado. Nos anos 1980, a situação mudou para um papel de fornecimento de um aparato para uma economia amplamente desregulada e aberta. Também tornou-se evidente que algumas economias capitalistas do Leste Asiático estavam crescendo tão rapidamente que se tornariam «desenvolvidas» em um futuro próximo, marcando-as como completamente excepcionais. Economistas do mainstream explicaram seu sucesso como resultado da adoção das receitas ocidentais, enquanto outros estudiosos atribuíram esse rápido crescimento ao "Estado Desenvolvimentista". Este ensaio compara essas duas explicações para o desenvolvimento econômico bem-sucedido, concluindo em favor do último. O artigo também analisa os acontecimentos posteriores. Vários estudiosos que aceitam o papel fundamental do estado desenvolvimentista no período inicial de rápida industrialização no leste da Ásia passaram a argumentar que a Coreia do Sul, Taiwan e Cingapura se transformaram de estados desenvolvimentistas em estados quase neoliberais. Essa contribuição argumenta que os antigos Estados desenvolvimentistas do Leste Asiático realmente mudaram, mas não se transformaram em estados neoliberais. Em vez disso, eles se adaptaram e evoluíram, mas ainda assumem papéis de "missão social" de direção de mercado, muito além dos limites neoliberais. $\mathrm{O}$ ensaio também sugere como outros países em desenvolvimento podem aprender lições dessa experiência.
\end{abstract}

Palavras-chave: Desenvolvimento, Estado desenvolvimentista, neoliberalismo, industrialização.

\begin{abstract}
Before the 1980s, the mainstream Western prescription for developing countries to catch up with the West assigned the state a leading role in governing the market. In the 1980s, this shifted to a framework-providing role in a largely deregulated and maximally open economy. Also in the 1980s, it became apparent that some East Asian capitalist economies were growing so fast that they would become 'developed' in the foreseeable future, marking them out as completely exceptional. Mainstream economists explained their success as the result of following the Western prescription, while other scholars attributed this rapid growth to 'the developmental state.' This essay compares these two explanations of successful economic development, concluding in favour of the latter - with respect to the catch-up decades. But what happened subsequently? Several scholars who accept the key role of the developmental state in the early period of fast industrialization in East Asia now argue that South Korea, Taiwan and Singapore have transformed from developmental to close-to-neoliberal states. This contribution argues that the erstwhile East Asian developmental states have indeed changed, but they have not transformed into neoliberal states. Rather they have adapted and evolved, but still undertake market-steering, 'societal mission' roles well beyond neoliberal limits. The essay also suggests how other developing countries can learn lessons from their experience.
\end{abstract}

Keywords: Development, Developmental State, Neoliberalism, Industrialization

\footnotetext{
* Professor da London School of Economics. Esse artigo é uma versão traduzida ao português do original publicado em Development and Change, vc. 49, n. 2, pp 518-546. Traduzido e revisado por: Flavio Gaitán, Carlos Eduardo Santos Pinho e Ana Célia Castro.
} 


\section{O ASCENSO DA MENTALIDADE DA GLOBALIZAÇÃO}

Desde os anos 80, tem sido comum afirmar que o pacote de forças conhecido como "globalização" restringiu o "espaço político" de todos os Estados, alegando que existe, de fato, apenas uma receita institucional e política amplamente eficaz para o rápido crescimento econômico, conhecido como Consenso de Washington, que também poderia ser chamado de Consenso Ocidental. O Estado deve fornecer - ou assegurar a provisão privada de - uma gama de bens públicos que não são do interesse de empresas privadas que buscam lucro, que incluem infraestrutura física, mercados livres, estabilidade macroeconômica e uma estrutura institucional para o Estado de direito. O Estado não deve, exceto ocasionalmente nas margens, tentar influenciar a alocação de recursos, dar impulso direcional. Seja em economias avançadas ou em desenvolvimento, a alocação de recursos deve ser deixada principalmente para a interação de consumidores e produtores privados.

A justificativa subjacente para isso é a afirmação de que a competição entre agentes econômicos privados é o únicoprincípio organizador legítimo para o bem-estar social da atividade humana. A competição estimula habilidades criativas e empreendedoras e produz uma alocação eficiente de recursos. A "intervenção" do Estado deve ser muito limitada, porque os custos sociais que gera - incluindo a perda do valor mais prezado, a liberdade individual - provavelmente serão mais altos do que os ganhos sociais, mesmo quando "falhas de mercado" puderem ser identificadas. Quanto maior a escala, melhor: se a concorrência for a escala global, o ganho de cada país será maior. Qualquer forma de proteção ou subsídio é susceptível de ser considerado um empecilho para a eficiência, equivalente a atirar pedras em seu próprio porto.

A fonte dessa santificação do "mercado" foi Friedrich Hayek, que experimentou em 1936 o que ele descreveu como uma "iluminação súbita": "Como a combinação de fragmentos de conhecimento existentes em mentes diferentes poderia produzir resultados que, se fossem intencionalmente aportados, exigiriam um conhecimento por parte da mente direcionadora que nenhuma pessoa pode possuir?" (citado em Metcalf, 2017). Ou, como Margaret Thatcher costumava dizer: "Você sempre gastará a libra no seu bolso melhor do que o Estado".

Essas declarações refletem uma mentalidade frequentemente chamada de "neoliberal". A mesma prioriza a "saída" por sobre a "lealdade", o que significa "manter as opções abertas", "minimizar o comprometimento", para que os recursos possam ser rapidamente transferidos para alternativas mais lucrativas. O Le Monde certa vez chamou-a de cette attitude trés anglo-saxon-le "wait and see". Hayek usou o termo com conotações positivas, assim como seus seguidores, mas na década de 1980 esses seguidores se descreveram como neoclássicos ou apenas liberais e "neoliberal" passou a ser usado principalmente pelos críticos. Nesse artigo eu uso o termo em um sentido mais analítico, para denotar uma certa mentalidade cognitiva e normativa. 
As ideias neoliberais tornaram-se imensamente poderosas em moldar o conteúdo da "reforma" institucional e política. As organizações inter-estatais diretamente preocupadas com o desenvolvimento econômico nos países em desenvolvimento (Banco Mundial, Fundo Monetário Internacional (FMI), Comitê de Assistência ao Desenvolvimento (DAC) da Organização para Cooperação e Desenvolvimento Econômico (OCDE), a maioria parte das agencias das Nações Unidas ligadas ao desenvolvimento e vários bancos de desenvolvimento regional) contribuíram a impulsionar o poder das ideias neoliberais desde a década de 1980 (Krueger, 1990). O mesmo acontece com economistas acadêmicos ocidentais e líderes empresariais. Mencionamos aqui alguns exemplos da mentalidade neoliberal

Um jornalista do New York Times cobrindo a reunião do World Economic Forum em 2002 escreveu que executivos e líderes do governo presentes acreditavam que "uma nação que abre sua economia e mantém mínimo o papel do governo invariavelmente experimenta um crescimento econômico mais rápido e uma renda crescente". (Uchitelle, 2002). Percy Barnevik, enquanto CEO da multinacional sueco-suíça Asea Brown Boveri (ABB), afirmou:'Eu definiria globalização como a liberdade do meu grupo para investir onde e enquanto desejar, produzir o que deseja, comprando e vendendo onde quer que deseje (...) enquanto atura o mínimo possível de leis trabalhistas e restrições de convenções sociais" (citado em Gelinas, 2003: 21). Bernard Arnault, CEO do grupo de luxo francês LVMH e a décima pessoa mais rica do mundo em 2000, disse: "As empresas, especialmente as internacionais, têm recursos cada vez maiores, e na Europa adquiriram a capacidade de competir com os Estados ... O real impacto dos políticos na vida econômica de um país é cada vez mais limitado. Felizmente" (citado em Halimi, 2013). Em 1988, James Riedel, então professor de Economia Internacional na Universidade Johns Hopkins, explicou o excepcional sucesso de desenvolvimento dos países do leste asiático:

As lições políticas que derivam das experiências dos países da Ásia Oriental são simples e claras e, por essa razão, são prontamente ignoradas ou descartadas. [As lições são que] os princípios econômicos neoclássicos estão vivos e funcionam de maneira particularmente eficaz nos países do Leste Asiático. Uma vez que os bens públicos sejam providos e as distorções mais óbvias sejam corrigidas, os mercados parecem fazer o trabalho de alocar recursos razoavelmente bem e certamente melhor do que a tomada centralizada de decisões. Isso é evidente no Leste da Ásia e na maioria das outras partes do mundo industrial e em desenvolvimento, e é, afinal, o principal dogma da economia neoclássica. (Riedel 1988: 38, ênfase própria; ver mais adiante, Wade, 1992a)

Uma versão mais sutil do argumento apareceu no livro de alto perfil Milagre do Leste Asiático, do Banco Mundial, publicado em 1993. O livro selecionou oito'economias asiáticas de alto desempenho': o Japão, as três economias recém-industrializadas de primeira geração do Sul (Coreia, Taiwan e Cingapura), e as três economias do sudeste asiático de segunda geração (Tailândia, Malásia e Indonésia), além de Hong Kong. 
O argumento é que os Estados fizeram contribuições importantes para o rápido crescimento desses países, garantindo "os fundamentos": inflação baixa e taxas de câmbio competitivas; capital humano; sistemas financeiros eficazes e seguros; baixas distorções de preço; tecnologia estrangeira; e baixo preconceito contra a agricultura. No entanto, as intervenções "estratégicas" -promovendo indústrias específicas"geralmente não funcionaram" (Banco Mundial, 1993: 354). A mensagem a ser divulgada, disse o Banco Mundial, era: "A abertura ao comércio internacional, baseada em incentivos amplamente neutros, foi o fator crítico no rápido crescimento do Leste Asiático" (ibid.: 292, ênfase própria).

A origem do estudo Milagre do Leste Asiático está nas críticas feitas por altos funcionários do Banco Mundial aos programas de ajuda do Japão no Sudeste Asiático, nos quais o crédito direcionado e subsidiado era um componente importante. O Ministério das Finanças do Japão (MOF), que ajudou a projetar e operar os programas de crédito, ofendeu-se com a alegação do banco de que o crédito dirigido apenas distorcia os mercados financeiros (até porque o MOF considerou que seus programas de crédito dirigido durante as décadas do pós-guerra foram sua maior contribuição para o "milagre japonês"). O MOF, em algum sentido, obrigou o relutante Banco a empreender um estudo do Nordeste e do Sudeste Asiático, para identificar as causas do relativo sucesso da região. O banco não conseguiu afastar o pedido do Japão, porque o Japão era o segundo acionista do Banco e o MOF colocou US \$1,2 milhão na mesa para financiar o estudo. Depois que o estudo foi publicado, altos funcionários do Banco informaram ao mundo que o organismo já entendia suficientemente as causas do rápido desenvolvimento econômico no leste e sudeste da Ásia, não realizariam mais pesquisas sobre a questão e se concentrariam em divulgar a mensagem sobre a importância de liberalizar os mercados e integrá-los na economia mundial a governos de outros lugares, na América Latina e especialmente na África. ${ }^{1}$

Assim, o Banco Mundial conseguiu mostrar que as histórias de sucesso do Leste e do Sudeste Asiático confirmaram a receita que vinha instando a todos os países em desenvolvimento desde o início dos anos 1980, mais tarde descrito como Consenso de Washington, especialmente a prioridade da liberalização comercial. De fato, os Empréstimos para Ajustes Estruturais do Banco Mundial durante a década de 1980 levaram mais condições de liberalização do comércio do que aqueles em qualquer outro domínio político. O Banco tratou a liberalização do comércio como a rainha das políticas, não apenas uma entre muitas, alegando que a política de livre comércio limitaria a quantidade de danos gerados por outras intervenções do governo no mercado (Banco Mundial, 1989).

Avançando em direção a 2008, Justin YifuLin foi nomeado economista-chefe e vice-presidente sênior do Banco Mundial. De nacionalidade chinesa, com doutorado em economia pela Universidade de Chicago, foi o primeiro economista-chefe de um país que não faz parte do G7 (a maioria dos presidentes foram dos Estados Unidos ou da Grã Bretanha). Lin tentou acabar com a anterior eliminação da expressão “política 
industrial" no vocabulário do Banco Mundial, avançando a idéia de que alguma promoção seletiva de certas indústrias poderia ser apropriada desde que as indústrias promovidas estivessem dentro do contexto davantagem comparativa existente na economia do país e que sua promoção não fosse uma tentativa ousada de acelerar a melhoria da vantagem comparativa criando um novo conjunto de indústrias de maior valor agregado (ou segmentos de cadeias produtivas regionais). Lin se aproximou de vários vice-presidentes regionais no Banco Mundial com a ideia de que poderiam organizar alguns projetos-piloto. A resposta geral foi negativa. Um dos economistas seniors da vice-presidência de Lin declarou-me com um aceno de desprezo: "Para cada Coréia há cem fracassos. Em qual você investiria?"'(Comunicação pessoal, 2010). O próprio Lin admite que durante seu tempo como economista-chefe, menos de $10 \%$ dos economistas do Banco Mundial eram simpatizantes de seus argumentos (comunicação pessoal, 2010).

Alguns projetos piloto foram adiante, sob o nome "Programa de Indústrias Competitivas". Mas o sucessor de Linna direção das pesquisasnomeou um Diretor de Política de Desenvolvimento para o que, segundo um colega, "se opõe fortemente a qualquer forma de estratégia governamental ativa" (comunicação pessoal, julho de 2014). E na operação do complexo de pesquisas, o recém-nomeado Diretor Sênior, mais relevante para a continuidade do Programa de Indústrias Competitivas, fechou-o com base no fato de que "ela entende a política industrial apenas como as políticas fracassadas de substituição de importações implementadas na América Latina nos anos 1960". (comunicação pessoal, Julho de 2014). Após o período de Lin, o Banco dificilmente se engajou com política industrial.

Em suma, o entendimento geral das causas do crescimento rápido e sustentado no Leste Asiático enfatiza que os governos não "distorceram" os mercados com "intervenções" excessivas e que os governos corrigiram algumas falhas do mercado (inclusive fornecendo uma série de bens, incluindo o "estado de direito"). Dessa forma, os governos "acertaram os preços", o que significa que eles permitiram que os preços domésticos se alinhassem com os preços internacionais, à medida em que se reduz a proteção ao comércio e os subsídios domésticos ao longo do tempo. As decisões orientadas para o lucro de investidores e produtores fizeram com que a estrutura de produção evoluísse de acordo com a mudança da vantagem comparativa à medida que a renda média da economia crescia e suas dotações se expandiam.

Essa interpretação faz do sucesso capitalista do Leste Asiático uma valiosa validação da resposta do neoliberalismo à grande questão de Adam Smith, de como a economia capitalista gera o bem-estar humano. A chave para o sucesso é a alocação de recursos por meio de mercados, que se auto-ajustam em grande parte por meio da concorrência de preços. O pressuposto subjacente é que cada unidade de PIB adicional tem o mesmo impacto no crescimento de longo prazo como qualquer outro, independentemente do setor de onde vem; portanto, não há necessidade de orientação da produção do Estado para setores cuja produção tenha um impacto maior no 
crescimento de longo prazo ${ }^{2}$. Essa ideologia já estava ascendendo no Ocidente no final da década de 1970 e projetada nos países em desenvolvimento durante a década de 1980 (Wade, 2003, 2015).

Este ensaio, que conclui o Debate do Fórum de 2018 sobre "Financeirização e Desenvolvimento Econômico", compara essa explicação econômica dominante da rápida industrialização e "catch-up" de vários estados da Ásia Oriental com o argumento do "Estado desenvolvimentista". As seções que seguem enfocam diferentes aspectos do excepcional desenvolvimento econômico da Coreia do Sul, Taiwan e Cingapura, e chegam à conclusão de que o Estado desenvolvimentista - embora tenha se adaptado e evoluído - está longe de estar extinto. A seção final sugere algumas lições que outros países em desenvolvimento podem aprender com a experiência desses três estados.

\section{EXPLICANDO AS EXPERIÊNCIAS DE ALCANÇAMENTO (CATCH-UP) DOS PAÍSES ASIÁTICOS}

Poucos países não ocidentais se desenvolveram nos últimos dois séculos. Mesmo ampliando os limites de "não-ocidentais", "país" e "desenvolvidos", a lista é menor que 10 - incluindo Japão, Rússia, Taiwan, Coreia do Sul, Hong Kong, Cingapura e Israel. A ascensão de todos, exceto os dois primeiros, data da Segunda Guerra Mundial. O principal padrão de crescimento de longo prazo na economia mundial tem sido: "grande momento de divergência" (Pritchett, 1997). Um estudo do Banco Mundial (2013) identifica 101 países como'renda média' em 1960, dos quais apenas 13 haviam atingido 'alta renda' quase 50 anos depois, em 2008. ${ }^{3}$ Esta proporção muito baixa especialmente quando ilhas e campos de petróleo são deixados fora - dá substância às metáforas do "teto de vidro" e da "armadilha de renda média" na economia mundial (Wade, 2016).

Os "tigres asiáticos" (Taiwan, Coréia do Sul, Hong Kong, Cingapura) são considerados promotores da era do pós-guerra, ainda mais devido ao seu ponto de partida na década de 1950, com poucos recursos naturais, altas taxas de pobreza e uma emergência tumultuada como Estados soberanos (Hong Kong à parte). Casos de países com crescimento contínuo a 6\% ao ano ou mais por mais de 15 anos são incomuns. Até 2010, Taiwan detinha o recorde mundial de 32 anos (1962-1994), seguido pela Coreia do Sul de 29 anos (1962-1991). Em 2010, a China quebrou o recorde mundial; ela cresceu continuamente a mais de $6 \%$ durante 33 anos (Pritchett e Summers, 2014). A Tabela 1 fornece um instantâneo da trajetória de desenvolvimento econômico de vários estados asiáticos, incluindo alguns dos Tigres. 
Tabela 1. Crescimento promédio como \% do crescimento real da renda dos Estados Unidos (em dólares Geary-Khamis de 1990)

\begin{tabular}{l|c|c|c|c|c}
\hline & Japão & Taiwan & Coréia do Sul & Malásia & Indonésia \\
\hline 1965 & 45 & 15 & 15 & 15 & 10 \\
\hline 2005 & 75 & 65 & 60 & 30 & 10 \\
\hline
\end{tabular}

Nota: \% arredondado para o ventile mais próximo.

Fonte: Base de dados de Angus Maddison (The Maddison-Project, www.ggdc.net/maddison/maddison-project/home.htm, versão2013) e FMI International Financial Statistics (https://bit.ly/2IUyeSR).

\section{LIÇŌES DA ECONOMIA DO MAINSTREAM DAS EXCEÇÕES DO LESTE ASIÁTICO}

A ascensão dos três asiáticos do leste ${ }^{4}$ provocou um debate sobre as razões de seu excepcional sucesso. Como sugerido anteriormente, a maioria dos economistas e as principais organizações multilaterais de desenvolvimento controladas pelo Ocidente, incluindo o Banco Mundial, o FMI, a OCDE e seu Centro de Desenvolvimento, ressaltaram a liberalização dos mercados, incluindo o comércio de bens e serviços, investimento e finanças, e abertura à economia internacional. Produtores e consumidores nesses territórios tornaram-se cada vez mais capazes de aproveitar as oportunidades de lucro e satisfação do consumidor disponíveis num espaço econômico maior. Assim, a ascensão dos casos capitalistas do leste asiático confirmou a verdade da teoria da globalização e a receita política do Consenso de Washington. Se outros países em desenvolvimento também se liberalizassem e se integrassem firmemente na economia internacional, também poderiam recuperar o atraso, especialmente com todas as oportunidades disponíveis nas cadeias globais de valor desde os anos 90 . A economia mundial é, por suposição, um sistema aberto, sem segmentações ou obstáculos estruturais à ascensão dos países em desenvolvimento.

\section{A "TEORIA" DO ESTADO DESENVOLVIMENTISTA DO SUCESSO DA ÁSIA ORIENTAL}

A principal explicação econômica para o sucesso do Leste Asiático é tão curta a ponto de relembrar o intercâmbio de Alice com o Rei Através do Espelho:

"Não vejo ninguém na estrada", disse Alice.

"Eu só gostaria de ter esses olhos", o rei comentou em tom irritado. Para poder ver ninguém! $E$ a essa distância também! Por que, isto é o que eu posso fazer para ver pessoas reais por essa luz.'

Agora temos um corpo considerável de literatura sobre o Estado desenvolvimentista na Ásia Oriental (uma frase cunhada por Chalmers Johnson em seu estudo de 1982 sobre a ascensão do Japão; ver também Haggard, no prelo). Emanando principalmente 
de cientistas políticos, economistas políticos e historiadores, essa literatura tende a ter pouco envolvimento direto com a economia convencional (e vice-versa). Ambos os lados reivindicam a verdade, mas um observador imparcial deve concluir que nenhum dos lados produziu "vidências eliminatórias" (Rodrik, 2012). É difícil encontrar "fontes exógenas" de variação a partir das quais testar a causalidade "rigorosamente" (uma fonte exógena de variação pode ser o impacto de um asteroide ou a eleição do Presidente Trump).

A teoria do Estado desenvolvimentista do sucesso capitalista do Leste da Ásia parte do fato de que essas economias conseguiram desenvolver principalmente empresas de propriedade nacional em uma ampla gama de grandes indústrias globais, capazes de atuar como fornecedores de primeira linha para corporações multinacionais e até competir cabeça-a-cabeça com eles. A gama incluiu produtos químicos, petroquímicos, eletrônicos, aço, construção naval, carros ou peças de automóveis. A questão é como eles o fizeram, quando a grande maioria dos países não o fez. A teoria enfoca no síndrome da política, ideias, arranjos institucionais e políticas dos três principais casos durante suas décadas de industrialização extremamente rápida após a Segunda Guerra Mundial (Thurbon, 2014, 2016). Implícita ou explicitamente, a teoria compara os casos do Leste Asiático ao modelo neoliberal, ou Consenso de Washington (Weiss, 1998).

No nível político e de ideias, o modelo neoliberal assume um consenso da elite sobre as vantagens de eficiência e crescimento de mercados mais ou menos livres, incluindo alta integração na economia mundial. Em contraste, o modelo de Estado desenvolvimentista (inferido dos casos do Leste Asiático) assume no nível político um consenso de elite sobre o seguinte:

1. Alta prioridade dada à obtenção de taxas elevadas e sustentadas de crescimento econômico, a fim de alcançar os países desenvolvidos "rapidamente" (em algumas décadas);

2. Taxas de investimento muito altas em relação ao PIB, de modo a obter um movimento rápido da estrutura de produção para atividades de maior produtividade;

3. A necessidade de o Estado coordenar a estratégia de recuperação e promover alguns setores e funções à frente de outros, seja por meio de empresas públicas ou por meio da condução de atores privados em setores que de outra forma não entrariam;

4. A necessidade de o Estado coibir o crescimento do consumo da força de trabalho urbana e dos agricultores, de modo a liberar mais recursos para o investimento;

5. A necessidade de o estado promover ativamente as exportações, para que o alto investimento possa ser rentável, apesar do crescimento restrito do consumo em casa. Ao mesmo tempo, a política industrial do Estado deve visar à substituição viável de importações e concentrar o câmbio nas importações de bens de capital, 
bens intermediários e matérias-primas (não bens de consumo) por meio de uma política comercial administrada, não de livre comércio.

Subjacente a esse consenso da elite está o reconhecimento de que os recursos de investimento são muito escassos e devem ser cuidadosamente protegidos. A elite não tem compromisso com a ideia de que "mercados livres" ou alta integração na economia mundial produzirão a estrutura ótima de produção ao longo do tempo.

Nos casos do Leste Asiático, o conteúdo da estrutura de produção ideal a ser visada era influenciado por metáforas populares de desenvolvimento econômico, como a descida de um rio ou a formação de gansos em forma de V. Oficiais da Coreia do Sul e Taiwan viram suas economias descendo o mesmo trecho do rio, ou voando na mesma formação em V, como o Japão, cerca de 10 a 20 anos antes. Eles poderiam olhar para a estrutura de produção passada do Japão para uma indicação tangível do que deveriam estar desenvolvendo (qualificada, é claro, pelo conhecimento dos desenvolvimentos atuais em tecnologia e mercados, especialmente no Japão e nos EUA). O modelo neoliberal não tem equivalente, pois a ideia de tal bússola contradiz o ponto básico da "iluminação súbita" de Hayek, citada anteriormente. Essas ideias sobre um projeto nacional de desenvolvimento exemplificam o que Elizabeth Thurbon (2016) descreve como "a mentalidade desenvolvimentista".

O que seguem são arranjos institucionais. O modelo neoliberal enfatiza a necessidade de verificações e balanços entre os vários ministérios governamentais preocupados com a política econômica, de modo que a autoridade do nível central é descentralizada horizontalmente, sem nenhum ponto focal para assegurar a cooperação entre ministérios alinhada a uma estratégia de investimento em toda a economia. Além disso, o modelo enfatiza as relações de braços compridos entre as agências governamentais e os empresários, para evitar o perigo sempre presente destes capturarem o governo, considerando a propensão dos burocratas de um comportamento "oportunista". E enfatiza a necessidade de um Banco Central independente com estabilidade de preços como seu objetivo número um, e para o resto do setor bancário tomar a forma de bancos comerciais privados.

No Estado desenvolvimentista, o poder burocrático é altamente centralizado significando que o poder é concentrado horizontal e verticalmente (um ou alguns ministérios são dominantes, como o MOF e o MITI - o Ministério do Comércio Internacional e Indústria - no Japão do pós-guerra, e o poder é concentrado no topo dos ministérios), em forte contraste com, digamos, a Grécia (Wade, 2012). Em segundo lugar, o Banco Central não é independente dasprincipais lideranças políticas (em Taiwan, o governador tem status de membro de gabinete) e o resto do setor bancário inclui uma grande presença de bancos estatais, através dos quais indústrias e empresas estrategicamente designadas podem ser atingidas. Os movimentos de capitais entre fronteiras são controlados ferreamente. Em 1999, o governador do Banco Central de Taiwan ficou horrorizado ao saber que a equipe de Taiwan que negociava a filiação à OMC estava prometendo abandonar os controles de capitais. Sua resposta foi recrutar 
funcionários com PhDs em engenharia financeira para construir controles secretos nas entranhas do Banco Central (comunicação pessoal, 1999).

Terceiro, o Estado desenvolvimentista ganha alta "capacidade" de arranjos institucionais de "autonomia inserida", para usar a frase aparentemente oximorônica de Peter Evans (Evans, 1995; Woo, 1991). Isso significa que o Estado e seus funcionários têm uma estreita relação de trabalho com os capitalistas, mas também a capacidade de disciplinar capitalistas e capital. Têm a autonomia necessária para formular e implementar uma visão estratégica para o crescimento futuro da economia e disciplinar os proprietários e gestores de capital em consonância com essa visão; enquanto eles também mantêm relações próximas o suficiente com esses proprietários e gerentes de capital para obter feedback de informações e adesão corporativa ao projeto nacional.

A autonomia inserida é uma condição necessária, mas não suficiente, para um Estado desenvolvimentista efetivo. O Banco da Inglaterra, como assinala lain Pirie (2017), há muito tempo tem alta autonomia (e recebeu total responsabilidade operacional pela política monetária em 1998), ao mesmo tempo em que há muito tempo está "incorporado" às relações com o setor privado. Ele usou essa posição para promover a exposição de empresas no Reino Unido às pressões competitivas globais, não para desempenhar um papel na formação da estrutura de produção (além de impulsionar Londres como um centro financeiro global). Ninguém acusaria o Banco da Inglaterra de ser um pilar do Estado desenvolvimentista. Usou sua autonomia inserida para defender as políticas neoliberais.

Devemos também notar que a parte "inserida" da autonomia inserida não incluiu muitos insumos dos sindicatos, especialmente na Coreia do Sul e em Taiwan antes do final dos anos 80, quando ambos passaram da regra de partido único ou militar para uma forma de democracia. A repressão trabalhista e a marginalização política da classe trabalhadora, eram parte do modelo, para manter baixos os custos trabalhistas, evitar que a demanda de consumo ameaçasseo ciclo de reinvestimento de lucros de investimento e manter a visão de negócios estatais de futuras transformações (Deyo, 1987; Kohli, 2004)

Nono nível político, o Estado neoliberal enfatiza: (a) inflação baixa, não pleno emprego; (b) maximização do valor ao acionista como o principal objetivo corporativo; c) máxima flexibilidade dos mercados de trabalho, minimamente limitada pelos sindicatos; e, claro, (d) globalização, ou alta integração entre a economia nacional e internacional em termos de comércio, investimento e finanças. Desde o surgimento das cadeias de valor globais (CVGs), o principal caminho para o desenvolvimento econômico é integrar-se a essas cadeias e aceitar a governança privada das empresas líderes (principalmente ocidentais, japonesas ou, ultimamente, chinesas) em cada CVG. A competição manterá a governança privada alinhada com o interesse social.

O Estado desenvolvimentista, por outro lado, usa seus poderes para impulsionar a produção para setores e produtos com retornos crescentes e economias externas, mantendo uma grande parte de propriedade nas mãos dos empresários nacionais e 
procurando o tempo todo oportunidades para substituir importações sofisticadas pela produção doméstica (nos sectores prioritários). Assim, implementa uma ampla gama de instrumentos, incluindo crédito direcionado, incentivos fiscais para investimentos (como reduções fiscais na produção de produtos atualmente na fronteira tecnológica do país), proteção comercial (combinada com um sistema de tarifas e descontos para que os produtores possam obter isenção tarifária dos insumos importados para as exportações enquanto pagam as tarifas sobre o que vendem no mercado interno) e negociação difícil com multinacionais que pretendem fazer investimentos estrangeiros diretos no território nacional (tais como requisitos de conteúdo local em uma planta de etileno ou uma fábrica de chips) (Enos e Park, 1988; Wade, 1990/2004, 1991). Richard Luedde-Neurath (1986) documenta os elaborados controles comerciais encobertos usados pelo governo coreano ao mesmo tempo em que se vangloriava no mundo de suas ondas de liberalização do comércio (ver também Wade, 1993, para a Coréia e Taiwan).

Em contraste com muitos outros governos que usavam instrumentos similares de tempos em tempos, os Estados desenvolvimentistas no leste da Ásia normalmente impuseramcondições de desempenho de algum tipo para acompanhar a assistência do Estado. As condições podem estar relacionadas com o fechamento da diferença de preço e qualidade entre importações e os produtos substitutos domésticos, ou com fomentar as fronteiras tecnológicas da produção doméstica (por exemplo, incentivos fiscais para os primeiros produtores que aumentarem os transformadores elétricos acima de uma determinada capacidade) (Amsden, 2001).

A proteção comercial não removeu a pressão competitiva internacional sobre os produtores. Ela protegia os produtores da pressão competitiva internacional até que os produtores conseguissem (quase) igualar o preço e a qualidade das importações concorrentes, ou falharem em fazê-lo (Wade, 1990/2004). Em ambos os casos, a assistência promocional foi retirada e redirecionada para outro lugar. Os efeitos foram muito diferentes da proteção em muitos outros DCs (e na Nova Zelândia antes da liberalização do Big Bang de 1984), onde foram dados sem condições de desempenho. Assim, ano após ano, a indústria automobilística indiana, protegida incondicionalmente, produzia limusines Ambassador baseadas na tecnologia automobilística britânica dos anos 50, até que alguns fabricantes estrangeiros de automóveis puderam montar a produção nos anos 80 .

Podemos resumir lembrando as principais condições iniciais do Estado desenvolvimentista do Leste Asiático: renda média baixa, poucos recursos naturais, escassez aguda de capital e um consenso da elite em torno da ideia de catch-up, que exigia taxas muito altas de investimento e re-investimento impulsionado pelo objetivo de diversificar a produção (não especializada) na direção das indústrias de alta tecnologia do Japão e do Ocidente. Daí o imperativo de: 
1. alocar capital escasso para maximizar a transformação econômica (especialmente a diversificação e modernização da indústria);

2. operar dentro de restrições de um sistema capitalista em que a maior parte da alocação de recursos ocorreu através do mercado e não através de um plano central;

3. obter grandes transferências de recursos do exterior, de modo a elevar a taxa doméstica de investimento além do que poderia ser de outro modo; e

4. construir institutos industriais de ciência e tecnologia, ligados a empresas privadas, começando no Japão nos anos 50 e seguidos por Taiwan e Coreia na década de 1960.

Esses esforços foram complementados por mecanismos para restringir a acumulação de riqueza não produtiva e o consumo de luxo. Em Taiwan, por exemplo, ficou entendido (a partir do início da década de 1980) que uma família poderia ter e alugar três ou quatro apartamentos sem atrair uma fiscalização por parte das autoridades fiscais, enquanto uma família que investisse claramente em imóveis alugados não seria poupada). Enquanto isso, uma família construindo negócios, especialmente aqueles orientados para as exportações, seria tratada com mais latitude, sendo as exportações um ponto focal das relações entre governo e negócios em geral. Em termos de classe, o Estado dominava as relações Estado-capital, e o Estado ajudava o capital a dominar as relações capital-trabalho (Deyo, 1987; Wade, 1990, 1990/2004).

\section{O ARRANJO DO PODER NO NORDESTE DA ÁSIA}

O que provocou a configuração de políticas, ideias, instituições e políticas nos três países do Leste Asiático que chamamos de Estado desenvolvimentista? O que motivou os principais atores nacionais a cooperarem entre si para formar uma "coalizão de crescimento" e concordarem em promover um investimento muito alto e um plano de desenvolvimento nacional para melhorar a estrutura de produção? Qual foi o fator de coesão da coalizão? É preciso lembrar que o projeto de desenvolvimento nacional implicava não apenas políticas sobre oferta monetária, taxa de câmbio, subsídios à exportação, proteção às importações e isenções fiscais, que poderiam ser decididas por pequenos grupos de tecnocratas isolados, mas também políticas de saúde, educação, treinamento e transporte, as quais necessitavam de extensas burocracias e impactavam diretamente a vida das pessoas em toda a sociedade. Como foi mantida a disciplina sobre as intervenções, em consonância com um projeto de desenvolvimento nacional, em vez de alimentar os mecanismos de apoio (como as redes de clientelismo) para manter um determinado grupo no poder, independentemente do custo para o projeto de desenvolvimento nacional? A literatura sobre o Estado desenvolvimentista presta pouca atenção a questões desse tipo (Doner e Schneider, 2016). ${ }^{6}$ 
Os arranjos de poder - ou "acordos políticos" - dos Estados desenvolvimentistas do Leste Asiático tinham vários aspectos em comum. A primeira foi a centralização de poder durante as décadas de rápida industrialização. Taiwan foi um Estado repressivo de partido único até o final dos anos 80. A Coreia foi uma ditadura militar repressiva até o final dos anos 80. Cingapura tem sido um Estado bastante repressivo, quase um partido. Hong Kong foi governada principalmente desde Londres até o final dos anos 90. Até o Japão chegou perto do governo de um só partido durante a maior parte do período desde 1955. O segundo foi que os governantes do pós-guerra enfrentaram pouca oposição das elites fundiárias. Japão, Taiwan e Coreia realizaram reformas agrárias por médio da expropiação de terras. Isso deixou as elites encarregadas do pós-guerra livres para direcionar recursos para os novos e mais produtivos setores econômicos. Em contraste, Filipinas não realizou reformas significativas, e o nexo entre proprietários rurais e governo continuou a exercer poder político e econômico e a reforçar a dependência do país da produção de commodities.

A terceira característica compartilhada foi a densa penetração das sociedades pelo Estado, com organizações destinadas a incorporar cidadãos de cima para baixo e, assim, minimizar a oposição política. Na pré-democrática Taiwan, por exemplo, toda indústria com mais de cinco firmas tinha que formar uma associação industrial, com um comitê eleito (então havia uma Associação de Exportadores de Penas de Taiwan); mas o secretário era nomeado pelo Estado e atuava como intermediário, inclusive para os serviços de segurança. Na Coreia, o Movimento Saemaul Undong (SU) estabeleceu um comitê em todas as aldeias, que poderia decidir como os recursos do SU seriam usados (por exemplo, para construir uma estrada de acesso, uma ponte, uma escola). Ao mesmo tempo, a SU -administrada por uma hierarquia gigante paralela ao Estado e sediada na Casa Azul, o escritório do presidente- era um mecanismo para identificar os líderes das aldeias e levá-los à Escola SU em Seul para "treinamento" (incluindo no patriotismo). Todos os três Estados combinaram vigorosa "socialização" no patriotismo e lealdade ao governo com a efetiva repressão dos dissidentes. O crescimento econômico foi rápido o suficiente, e a desigualdade de renda e riqueza foi baixa o suficiente, para garantir que quase todo mundo experimentasse o rápido aumento das condições de vida. Essa era a fórmula para produzir "consentimento" para os governantes. A incorporação altamente controlada dos cidadãos à estrutura e ethos do poder estatal e o projeto de desenvolvimento nacional ajudaram a gerar "capital social" e nacionalismo fervoroso ao longo de décadas, ajudados pela iminente presença da Coréia do Norte e da China continental (Wade, 1982).

Na época em que esses países começaram a se democratizar, nos anos1980, eles haviam experimentado décadas de crescimento rápido e uma incorporação cidadã rigorosamente disciplinada no Estado. A China hoje segue seu exemplo: controle político rigoroso de cima para baixo, vigorosa socialização no patriotismo, repressão selvagem dos dissidentes, juntamente com a rápida transformação da produção e da vida rural a urbana. O último implica uma liberalização considerável dos mercados, 
o que pressiona os assentamentos políticos existentes ou a "divisão de espólios"tensões que devem ser contidas pelo controle de cima para baixo via Estado, lei e Partido Comunista, até o ponto em que todas as religiões devem considerar o Partido comunista como sua mais alta autoridade.

\section{A "SORTE" DE LOCALIZAÇÃO E TEMPO}

Os estados do nordeste da Ásia foram "afortunados" em vários aspectos relacionados à localização e ao tempo. Primeiro, eles enfrentaram Estados inimigos comunistas por perto, o que contribuiu para a solidariedade da elite e a legitimidade popular. O constante medo da invasão e da insurreição doméstica, que poderia ser explorada por inimigos estrangeiros, ajudou a manter os governantes, políticos e funcionários disciplinados de acordo com a prosperidade nacional. Pelas mesmas razões, esses países receberam enormes quantias de apoio financeiro, técnico e militar dos EUA até meados da década de 1960, e continuaram com apoio militar em larga escala depois dessa data. No caso de Taiwan, as transferências financeiras dos EUA alcançaram, em média, cerca de 600 milhões de dólares por ano, de 1951 a 1965 (em dólares de 2016), a maior transferência de ajuda per capita do mundo naquela época. As autoridades de ajuda civil e militar dos EUA estavam particularmente atentas para assegurar o uso apropriado dos recursos que transferiram para Taiwan, bem cientes da história de alta corrupção no governo nacionalista durante suas décadas de governo no continente chinês antes da retirada a Taiwan, em 1949, em face da vitória comunista. Os recursos norte-americanos foram direcionados diretamente para empresas das indústrias de fertilizantes, transporte, cimento, alumínio, papel, vidro, açúcar, química, fibra sintética e farmacêutica. Autoridades dos EUA ajudaram a elaborar regulamentos para investimentos, zonas de processamento de exportação e similares. Eles sempre se opuseram às muitas pessoas de alto escalão do governo nacionalista, comprometidas em estabelecer novas empresas como empresas públicas, e não como empresas privadas. Eles colocaram seu peso atrás daqueles que queriam uma forte liderança estatal de uma economia amplamente de setor privado. A ex-colônia das Filipinas, por outro lado, recebeu muito menos apoio dos EUA, porque não estava na linha de frente da "esfera de influência" dos EUA emergentes no Pacífico ocidental, e não fazia parte da estratégia de "conter o comunismo". E as autoridades dos Estados Unidos aqui permaneceram relaxadas, à medida que os recursos da ajuda alimentavam as redes de clientelismo e corrupção dominadas pelos latifundiários, ao contrário de suas contrapartes no leste da Ásia (Lee, 2017).

Em segundo lugar, tendo poucos recursos naturais, os países do nordeste da Ásia escaparam da "maldição dos recursos naturais". Muitos DCs exportadores de recursos naturais tiveram supervalorização das taxas de câmbio em relação à taxa de câmbio na qual os fabricantes poderiam ser competitivos. Seus governos estiveram 
frequentemente baseados no controle de enclaves de recursos naturais, apoiados por corporações multinacionais e governos ocidentais. Nesses casos, a ideia de um projeto nacional de desenvolvimento provavelmente permanecerá no reino da retórica. A República Democrática do Congo, rica em minerais, é um caso paradigmático dramático. Tinha cerca de 112.000 km de estradas pavimentadas em 1949. Em 2004, tinha cerca de 1.000 km, ligando principalmente minas e portos (Butcher, 2007: 139).

Terceiro, as economias do nordeste da Ásia desenvolveram a produção bem antes que a China, o Vietnã, a Indonésia e outros países populosos e de baixo custo quase fechassem a entrada com mão de obra intensiva e baixos salários.

Em quarto lugar, os países mencionados praticaram a "intervenção estatal" numa época em que bancos estatais, proteção comercial, subsídios direcionados, controles de preços e "errar os preços" ainda eram aceitos no Ocidente como instrumentos legítimos de desenvolvimento nacional, antes da "mudança de época"7 da revolução neoliberal, a formação da OMC e a proliferação de "acordos de livre comércio" e "tratados bilaterais de investimento" dominados pelo Ocidente.

Quinto, eles construíram sua base industrial antes que o "despertar político global" levasse a demandas generalizadas por participação política na política nacional. Foi mais fácil, então, que os líderes estatais implementassem políticas industriais eficazes e restrições de mercado (por exemplo, acesso a moeda estrangeira) do que seriam hoje.

Dois pontos são importantes sobre a estratégia dos EUA. Primeiro, na visão dos EUA, o Japão seria o centro da economia regional do Nordeste Asiático, como antes da Segunda Guerra Mundial, com Taiwan e a Coreia do Sul como locais industriais semiperiféricos e de baixo custo, e todos os três receberiam acesso privilegiado ao mercado dos EUA. No momento em que um pequeno número de varejistas (por exemplo, o Walmart) começou a varrer os estabelecimentos familiares nos EUA e procurar fornecedores a granel em mercados de baixo custo, as empresas do Leste Asiático eram as mais óbvias a quem recorrer. As Filipinas e outras partes do Sudeste Asiático foram integradas à economia regional como exportadoras de commodities baratas para as economias industrializadas do norte. Essa divisão do trabalho permitiria que o comércio entre os países da economia regional e os do bloco comunista vizinho fosse minimizado como parte da estratégia de contenção (Lee, 2017).

Em segundo lugar, os altos níveis de apoio dos EUA permitiram que os países da Ásia Oriental incorressem em déficits sustentáveis de pagamentos externos durante seu estágio de rápida industrialização e urbanização -déficits cobertos pela assistência dos EUA. Mesmo usando níveis de proteção substanciais e estratégicos para promover a substituição de importações, eles sugaram enormes volumes de importações em setores selecionados. Em contraste, a maioria dos CDs, sem assistência externa em grande escala, não poderia sustentar os déficits de pagamentos externos que seriam necessários para rápida industrialização e urbanização -a menos que fossem financiados por empréstimos dos bancos multilaterais de desenvolvimento, os quais, 
desde a década de 1980 possuem condicionalidades neoliberais, ao contrário das condições dos EUA em sua assistência no leste da Ásia.

\section{EFEITOS ECONÔMICOS DO ESTADO DESENVOLVIMENTISTA}

É claro que os efeitos das "intervenções" dos Estados desenvolvimentas da Ásia Oriental nos mercados são controversos. A visão prevalecente entre os economistas ocidentais do desenvolvimento é que os efeitos eram insignificantes ou prejudiciais em relação ao que teria ocorrido com um papel estatal próximo do modelo neoliberal (como no volume Milagre do Leste Asiático discutido acima). Aqui limito a discussão a dois pontos: taxas de investimento sobre PIB observadas; e um estudo recente dos efeitos da unidade Heavy and Chemical Industries da Coreia do Sul.

A busca de altas taxas de investimento era um objetivo-chave do Estado desenvolvimentista do Leste Asiático. As tabelas a seguir ilustram que o objetivo foi amplamente alcançado. A razáo do investimento interno bruto em relação ao PIB de Taiwan saltou de 14\% em 1954 para 21\% em 1964 e para cerca de 40\% em 1974. A Coreia saltou de 10\% em 1960 para 36\% em 1970, no auge da unidade de Heavy and Chemical Industries; depois, caiu levemente, antes de subir para 39\% entre 1991 e 1996. A título de comparação, a cifra do Reino Unido para 1990 era de 19\%, sendo nos EUA de 17\% (Pirie, 2017). Os níveis muito altos de investimento no leste da Ásia também são mostrados na Tabela $2 .^{8}$

Tabela 2. Formacao bruto do capital (como percentagem do PIB)

\begin{tabular}{|l|c|c|c|c|}
\hline & 1970 & 1990 & 2012 & $1980-2014$ \\
\hline China & 33 & 36 & 47 & 40 \\
\hline $\begin{array}{l}\text { Ásia do Leste e } \\
\text { Pacífico } \\
\text { (sem a China) }\end{array}$ & 23 & 32 & 30 & 28 \\
\hline $\begin{array}{l}\text { LICs \& MICs (sem } \\
\text { Ásia do Leste) }\end{array}$ & 22 & 22 & 25 & 23 \\
\hline
\end{tabular}

Nota: $L I C s=$ países de baixa renda. MICs = países de renda media.

Fonte:World Bank World Development Indicators, 22 December 2015 (https://bit.ly/2AXL6os).

Nathan Lane (2017) usa análise detalhada de insumo-produto para investigar os efeitos da unidade de Heavy Chemical Industries $(\mathrm{HCl})$ da Coréia do Sul, cujo período formal foi de 1973 a 1979. O impulso da IHC foi motivado pela crise de segurança causada pela decisão do presidente Nixon em 1970 para retirar as tropas dos EUA da Ásia, deixando a Coreia do Sul exposta ao ataque norte-coreano. Foi formalmente encerrado quando o Presidente Park (cujo mandato começou após o golpe militar de 1961) foi assassinado em 1979. Seu objetivo era incubar as indústrias estratégicas importantes para a força militar e o crescimento futuro, copiadas da industrialização 
do Japão no pós-guerra anterior. Os principais instrumentos eram bancos estatais, subsídios de capital, subsídios a insumos intermediários importados e proteção seletiva ao comércio.

Lane (2017) chega a três conclusões principais. Primeiro, durante e após o período de $\mathrm{HCl}$, as indústrias visadas cresceram mais rápido em termos de produção e produtividade do que as indústrias não visadas, em relação ao período anterior a 1973; segundo, essas diferenças de crescimento persistiram depois que os principais elementos da política foram suspensos em 1979; e terceiro, houve fortes efeitos de transbordamento por meio de ligações de entrada-saída. Os setores não visados que estavam abaixo dos setores visados e tinham ligações fortes com setores visados cresceram mais rapidamente do que aqueles que tinham ligações fracas com setores visados, graças especialmente aos preços mais baixos dos insumos. A evidência para os setores a montante não visados é mais mista, particularmente porque eles enfrentaram uma maior concorrência de importações, intensificada por (em alguns casos) subsídios de capital para setores específicos para seus insumos intermediários importados.

Estudos semelhantes sobre os impactos das políticas industriais do Japão e de Taiwan não foram realizados (que eu saiba), mas não há razão para supor que suas conclusões seriam significativamente diferentes. Os resultados para a Coreia do Sul dificultam sustentar uma afirmação comum de que os países do Leste Asiático - que tiveram o melhor desempenho econômico do mundo nas décadas do pósguerra - teriam alcançado um desempenho ainda melhor com menos "intervenção governamental" nos mercados.

\section{OS RELATÓRIOS DA MORTE DO ESTADO DESENVOLVIMENTISTA SÃO EXAGERADOS}

Os Estados desenvolvimentistas do leste asiático eram obviamente autolimitados, tendo em vista: (a) o consenso da elite em torno do projeto de desenvolvimento nacional, (b) a burocracia do planejamento industrial, (c) o conjunto de instrumentos de direção industrial e (d) a repressão do trabalho, resultou da convicção compartilhada da elite do imperativo de taxas muito altas de investimento para melhorar rapidamente a estrutura de produção, elevar as condições de vida em massa para inibir a rebelião doméstica e apoiar um exército forte, aliado ao conhecimento de que muitas firmas domésticas não podiam competir "em igualdade de condições" com firmas de países desenvolvidos. À medida que as economias entraram ou chegaram perto de "alta renda", experimentaram o problema comum aos países desenvolvidos: tornaram-se menos capazes de gerar oportunidades de investimento lucrativas suficientes para absorver a poupança interna (especialmente dadas as várias políticas para restringir o consumo). Longe de uma grave escassez de capital, eles começaram a enfrentar uma abundância. Ao mesmo tempo, o nível geral de produtividade era agora alto o 
suficiente para a maioria das empresas não precisar de subsídios ou proteção para competir internamente ou no exterior.

Para lain Pirie, a transição da escassez de capital para a abundância de capital muda a lógica básica: E o estado não é mais "desenvolvimentista".

Faz sentido apenas definir um estado como desenvolvimentista se a mobilização de capital em busca de política industrial for o objetivo[econômico] primário do Estado. (...). A alocação de capital e as relações capital-trabalho foram amplamente mecantilizadas na Coreia e em Taiwan. Os elementos essenciais do projeto neoliberal estão presentes. O Estado desenvolvimentista está morto (Pirie, 2017: 34, ênfase pròpria).

No caso de Taiwan, o investimento no PIB caiu de cerca de 32\% em 1974-81 para 24\% em 1982-88 e para 22\% em 2001-12. Na Coréia, por outro lado, o investimento total no PIB aumentou até os anos 80 e 90, de 31\% em 1976-80, para 35\% em 19861990 e 31\% em 1998-2014; mas as altas taxas de investimento foram muito altas no tocante à relação capital-produto, de modo que a taxa de lucro foi muito baixa até os anos 2000s.

Os países ex-desenvolvimentistas da Ásia Oriental aproximaram-se do modelo do Estado neoliberal, diz Pirie. Eles "despolitizaram" a governança econômica e substituíram a "governança pelo mercado" de maneira bastante abrangente. Em particular: (1) O Estado retirou-se da relação trabalho-capital (retirada das negociações sobre salários e condições de trabalho), e contou com a "disciplina do mercado" -a ameaça do desemprego e a ameaça da falência- para manter a mão de obra sob controle do capital; e (2) O Estado se retirou da alocação de crédito, como pode se observar nos bancos centrais agora "independentes", e na grande maioria dos empréstimos sem nenhuma ligação com a criação de nova capacidade produtiva. $A$ maioria dos bancos estatais de Taiwan empresta principalmente para os consumidores, e as empresas investem com capital e financiamento de títulos ou lucros retidos. As grandes empresas da Coreia estão cheias de reservas em dinheiro e têm poucos empréstimos dos bancos. Assim, em ambos os casos, a relação capital-trabalho e a alocação de capital foram mercantilizados; o Estado fica marginalizado.

Outros estudiosos enfatizam diferentes mecanismos produzindo a mesma erosão (até mesmo "morte") do Estado desenvolvimentista, e não apenas no leste da Ásia. Um é o domínio das CVGs na produção mundial. Empresas que antes eram guiadas pelo Estado se destacaram e se casaram com CGVs sob a orientação de empresas líderes. Outro é o aprendizado dos governos sobre os perigos de "escolher vencedores" na fronteira da indústria de alta tecnologia (Sato, 2013; Wong, 2011; Yeung, 2014)

Certamente os antigos estados Desenvolvimentistas se moveram em uma direção neoliberal. O movimento foi mais fácil porque, como vimos, durante sua história como Estados desenvolvimentistas, o Estado resistiu em se mover em uma direção social-democrata para construir proteções sociais. Hoje, o bem-estar público ainda está subdesenvolvido e os obstáculos legais bloqueiam a ação coletiva entre a classe 
trabalhadora. O gasto público social como proporção do PIB permanece muito abaixo da média da OCDE, e a participação da força de trabalho em sindicatos independentes também fica muito aquém da média da OCDE. Os governos permitiram que a parcela dos salários na renda nacional continuasse caindo - em Taiwan, de 55\% em 1995 para apenas 48\% em 2011 (Pirie, 2017: 47). A desigualdade de renda tem aumentado constantemente desde os anos 1980s. Tudo isso se encaixa no modelo neoliberal. Um resultado é que, tanto em Taiwan quanto na Coreia, o caminho de um modelo de crescimento baseado no consumo, apoiado pelo aumento dos salários em linha com o aumento da produtividade, não é uma opção, dadas essas outras tendências que os governos não reverteram. O modelo de crescimento depende do aumento da dívida das famílias e da demanda externa -as exportações- para reduzir a lacuna na demanda, e ambas são fontes de vulnerabilidade. O superávit em conta corrente de Taiwan em relação ao PIB é quase o mesmo que o da Alemanha, em torno de $8 \%$. A maior parte do excedente é com a China -uma dependência que a China acolhe como uma tendência para a união política. O superávit em conta corrente da Coréia, em relação ao PIB, foi em média de 3\% nos anos 2000, a maior parte com a China (ibid .: 51). Ambos os países se tornaram altamente vulneráveis a uma crise econômica na China, ou formas de torção do braço.

No entanto, concluir que o Estado desenvolvimentista está erodido ao ponto da insignificância é ver com apenas um olho, pela razão dada por Elizabeth Thurbon:

\footnotetext{
As tentativas de distinguir entre tipos de Estado apenas pela observação de políticas são infrutíferas: todos os Estados intervêm em suas economias para apoiar e promover certos tipos de atividade econômica. O que distingue os Estados desenvolvimentistas dos outros não é a existência de intervenção per se, mas sim a ambição desenvolvimentista e o consenso da elite que enquadra essa intervenção e a existência de capacidades institucionais que ajudam a traduzir a ambição em resultados políticos mais ou menos eficazes. (Thurbon, 2014: 11, ênfase própria).
}

Evidência aduzida por Christopher Dent (2007), Lee, Heo e Kim (2014) e Linda Weiss (2003), entre outros, apoia as conclusões de Thurbon de que a "mentalidade desenvolvimentista" continua sendo um poderoso modelador da estratégia de desenvolvimento na economia industrial da Coreia e que há "pouca evidência ... [de] crescente oposição anti-estatista". "O apoio da indústria evoluiu em paralelo com a mudança de objetivos, há pouca evidência para sugerir que o Estado coreano abandonou tais práticas em indústrias baseadas na ciência.... Essas tarefas não se prestam à coordenação de cima para baixo. Mas isso não necessariamente os torna menos desenvolvimentistas" (Thurbon, 2014: 14).

Grande parte dessa liderança assume a forma de "missões sociais" abrangentes, impulsionadas por uma mistura variada de objetivos econômicos e de segurança nacional. Nas últimas décadas, todos os três casos (capitalistas) do Leste Asiático experimentaram um número estonteante de reestruturações organizacionais na busca de objetivos nacionais de inovação. Retrocedendo, pode-se ver, em primeiro 
lugar, um movimento bastante constante dos esforços para domesticar as inovações estrangeiras e implantá-las na economia doméstica (mitigar riscos para os adotantes), para gerenciar as incertezas de inovar na fronteira tecno-econômica global. Segundo, pode-se ver um caminho ziguezagueante ao longo do tempo, muitas vezes coincidindo com mudanças de governo: do controle descentralizado e razoavelmente centralizado (usando métodos de formulação, legitimação e implementação de políticas de inovação extraídas dos princípios do antigo Estado desenvolvimentista), para as mais descentralizadas "ilhas periféricas" das agências de inovação (com base na abordagem dos Estados paradigmáticos com fortes tradições neoliberais, como EUA e Reino Unido), e de volta para um controle mais central, com base em uma versão atualizada da mentalidade desenvolvimentista (Karo, no prelo).

Por exemplo, o governo coreano lançou um grande impulso para o "crescimento verde" no final dos anos 2000, estendendo-se de veículos totalmente elétricos a redes inteligentes e além. Este foi apenas um dos impulsos do seu programa mais amplo "577" - 5\% do PIB investido em P \& D, com foco em 7 áreas principais, para se tornar uma das 7 principais economias de ciência e tecnologia do mundo. De fato, Pirie reconhece da Coreia: "O papel do Estado na promoção da pesquisa colaborativa e no gerenciamento da competição vai muito além do que podemos esperar que um Estado neoliberal normal pratique" (Pirie, 2017: 35).

O governo de Taiwan aumentou a capacidade de pesquisa e desenvolvimento por muitas décadas. No início dos anos 1980 criou o Grupo Consultivo de Ciência e Tecnologia (STAG), composto por um ministro do gabinete, o Ministro da Ciência e Tecnologia, como presidente, e sete a dez assessores, todos estrangeiros, que se reuniam duas vezes por ano por espaço de uma semana, apoiada por um secretariado local. O grupo examinou a solidez das propostas de novas iniciativas em Taiwan e os desenvolvimentos no resto do mundo de relevância para Taiwan. Em meados da década de 1980, o Instituto de Pesquisa de Tecnologia Industrial (ITRI), financiado pelo setor público, tinha uma equipe de cerca de 10.000 pessoas divididas em institutos separados (como a Organização de Pesquisa e Serviços de Eletrônica, ERSO). O ITRI, por sua vez, instituiu múltiplas redes em empresas públicas e privadas, e facilitou para seus cientistas o desdobramento de aplicativos comerciais. Juntamente com o ITRI, havia uma contrapartida militar secreta com uma equipe de cerca de 20.000 pessoas (Wade, 1990/2004). Em 2012, a STAG foi transformada em um corpo mais formalizado, o Conselho de Ciência e Tecnologia (BOST), presidido pelo Primeiro ministro e incluindo chefes de agências-chave, indústrias, organizações de pesquisa e acadêmicos. Tudo isso faz parte de um esforço para combinar a criatividade de baixo para cima com o controle de cima para baixo, liderando muitas redes de participação, enquanto mantém a formulação de prioridades e controle sobre financiamento de inovação concessional no alto dos ministérios.

Isso é muito diferente do modelo neoliberal, caracterizado pelo consenso da elite de que mercados livres e competitivos gerarão a estrutura de produção ideal para uma 
economia nacional, com a inovação financiada com recursos públicos proveniente de ilhas de inovação descentralizadas. Os casos do Leste Asiático mantêm a capacidade - em termos de mentalidade (idéias e compromisso) e em termos de burocracia - de que o Estado dê impulso direcional em partes da economia, muito além dos princípios neoliberais, deixando a maior parte do restante sem alvo (untargeted).

lain Pirie os chama de Estados neoliberais com qualidades legadas do Estado desenvolvimentista, ou "Estados pós-desenvolvimentistas". No entanto, isso obscurece a mentalidade continuada de desenvolvimento que leva o Estado a continuar pressionando pela transformação da produção, considerada necessária para manterse à frente dos Estados inimigos comunistas próximos e evitar distúrbios domésticos. O Estado desenvolvimentista não "caiu" ou "desapareceu" no leste asiático em favor do Estado neoliberal, como Pirie afirma. Ele "evoluiu" em resposta a mudanças nos parâmetros. Nas palavras de Dent, "embora as ferramentas e os meios políticos possam ter mudado, os Estados desenvolvimentistas ainda presidem vários projetos econômicos adaptativos e transformadores que envolvem cada vez mais uma parceria com o capital transnacionalizado" (Dent, 2007: 227). Weiss diz sobre a Lei de Fusões e Aquisições Financeiras de Taiwan, que sua intenção de desenvolvimento é "promover empresas nacionais capazes de resistir à concorrência de empresas estrangeiras"(Weiss, 2003: 266). Em suma, devemos falar não da morte do Estado desenvolvimentista no leste da Ásia e da ascensão do Estado neoliberal ou pós-desenvolvimentista, mas da transformação do Estado desenvolvimentista de 1.0 para 2.0.

\section{FORÇAS ANTI-DESENVOLVIMENTO NA ECONOMIA MUNDIAL HOJE}

Como observado, poucos países não ocidentais se tornaram "desenvolvidos" nos últimos 200 anos. Além da enorme China e da pequena Taiwan (na costa da China), nenhuma economia nacional cresceu mais de $6 \%$ ao ano por 30 anos ou mais. Muitos outros conseguiram $6 \%$ ou mais por uma década, apenas para experimentar uma lenta desaceleração do crescimento (Broadberry e Wallis, 2016). Desacelerações agudas no crescimento são mais freqüentes entre os países de renda média que entre os países de renda baixa ou alta. A economia mundial parece conter algo análogo a um "teto de vidro" ou uma "armadilha de renda média".

A indústria de desenvolvimento surgida após a Segunda Guerra Mundial prometeu, desde a década de 1980, que a estratégia de catch-up deve centrar-se na integração da economia à economia internacional e, especificamente, nas CGVs, como se a modernização da estrutura de produção fosse então acontecer "por si só": "melhorar a troca(Exchange) e a produção seguirá". As justificativas são derivadas do paradigma neoliberal focado na troca(Exchange-focus) (não focado na produção), que apresenta a economia internacional como um sistema totalmente aberto, de modo que um país na escala de renda média é principalmente uma função de seus próprios recursos, 
localização, política, instituições e políticas. Como a posição de um maratonista é uma função de sua própria aptidão.

Essa concepção negligencia forças que tendem a perpetuar a estrutura hierárquica centro-periferia da economia mundial, que persiste de forma modificada mesmo com o crescimento populacional da China. Uma dessas forças é as GVC, amplamente anunciada como uma porta de entrada para as empresas de manufatura de DC entrarem em mercados estrangeiros - ao ponto de, como Milberg eWinkler (2013: 238) dizerem, "o objetivo da modernização industrial nas CGVs se tornou quase sinônimo de próprio desenvolvimento econômico". Menos notado é que as CGVs também criam barreiras aos processos de upgrading e à diversificação, como as cláusulas de escalonamento de tarifas -a menos que (possam participar) "a convite das" empresas dominantes (principalmente ocidentais). Uma segunda força é a alta concentração de conhecimento patenteado nas mãos de empresas ocidentais, especialmente nos setores de engenharia, instrumentos, química e farmacêuticos (Pagano, 2014, no prelo). Ambas as forças tendem a gerar lucros corporativos globais para empresas localizadas em um pequeno número de países predominantemente ocidentais, dando a essas empresas uma influência significativa sobre a política democrática - e sobre a política econômica externa, incluindo "acordos de livre comércio" e "tratados de investimento", os quais reforçam a estrutura centro-periferia (Starrs, 2014). O mesmo acontece com uma terceira força, a saber, a financeirização. Isso se refere tanto ao crescimento dos setores de FIRE (finanças, seguros, imóveis) em relação ao resto da economia, quanto à predominância do pensamento de 'maximizar o valor do acionista' na tomada de decisões corporativas, levando a restrições sobre o investimento produtivo (incluindo investimento privado em $P \& D$ ) e crescimento da remuneração dos executivos atrelada ao 'valor do acionista' (Lazonick, 2010).

Ao se integrarem fortemente ao sistema financeiro internacional, os CDs de renda média, como categoria, se tornam vulneráveis. Seus mercados domésticos de ativos e de crédito estão agora densamente povoados por investidores e organizações financeiras estrangeiras (elevando o passivo externo das economias), graças a que seus governos impuseram poucas regulamentações e restrições sobre entradas de capital estrangeiro, estabelecimento de instituições financeiras estrangeiras em seu território e acesso dos residentes aos mercados financeiros estrangeiros como mutuários e investidores. Além disso, as suas próprias empresas não financeiras tomaram grandes empréstimos nos mercados financeiros internacionais, aumentando ainda mais as responsabilidades externas das economias. Os países estão, portanto, expostos a ciclos de expansão- recessão nos principais países avançados, os EUA acima de tudo (Akyuz, 2017). Uma pesquisa recente mostra como os ciclos de longo prazo do dólar afetam o desenvolvimento econômico em CDs. A valorização do dólar (como em 1981-85, 1995-2002, 2008-09, 2012-15, quando o conjunto de dados termina) está associada a uma queda nos preços das commodities, uma queda no crescimento do PIB dos DCs, e um aumento no número de CDs enfrentando crises externas (devido à grande dívida 
em moeda estrangeira e fortes depreciações cambiais) (Chow et al., 2015; Druck et al., 2015).

Finalmente, nesta lista de forças anti-catch-up, vêm as regras de ajuste aos desequilíbrios de pagamentos. Desde o início da arquitetura de Bretton Woods em meados da década de 1940, o mecanismo para reduzir os déficits e superávits externos dos países colocou toda a pressão de ajuste sobre os países deficitários para reduzir seus déficits, sem pressão simétrica sobre os países superavitários para reduzir seus excedentes, tarefa muito mais fácil. No entanto, os países em desenvolvimento que investem pesadamente em infra-estrutura e capacidade de produção devem ser capazes de multiplicar as importações de materiais e bens de capital sem elevar seus déficits a níveis perigosos, o que seria mais viável se os países excedentes importassem mais e tivessem menores excedentes.

O complexo (compound) de CGVs, o monopólio do conhecimento, a financeirização e a pressão de ajuste assimétrico nos países deficitários geram uma convergência lenta ou de curto prazo da grande maioria dos CDs para a renda média e a produtividade dos países avançados (com exceção da China). O núcleo - o Ocidente - depende muito da renda proveniente da propriedade de ativos financeiros, patentes, marcas e direitos autorais de software, filmes e afins. Empresas ocidentais, especialmente americanas, ocupam os altos escalões das CGVs; e nos comandos as posições no topo são ocupadas por um pequeno número de empresas financeiras, que controlam as empresas da "economia real" através de participações e dívidas, e que conduzem cada GVC ao objectivo de maximização do valor doaccionista, gerando custos não pagos a vida no planeta e as forças de trabalho inseguras em todos os lugares (Vitali e Battiston, 2014). Nessa estrutura, os produtores dos países de baixa renda (como Bangladesh e Camboja) podem certamente se firmar nas indústrias de nível de entrada, como os têxteis, à medida que os custos sobem na China; mas aumentar as atividades de maior valor agregado é muito mais difícil.

A principal conclusão política é que o governo de um país de renda média pode elevar substancialmente a probabilidade de a economia sustentar o ímpeto ascendente na faixa de renda média através do ativismo, indo além dos limites do Consenso de Washington. No entanto, o ativismo é no máximo uma condição necessária, não suficiente; pode facilmente dar errado. O Estado brindando subsídios e proteção contra as condições de desempenho, e reforçando essas condições, é mais exigente (demanding) do que o Estado dar subsídios e proteção a amigos e parentes sem condições de desempenho, para consolidar o pequeno grupo no poder. Este último é o caminho para a corrupção em grande escala e o desenvolvimento econômico lento.

\section{ALGUMAS DIRETRIZES PARA OS PAÍSES DE RENDA MÉDIA HOJE}

Antes de concluir, esta seção oferece algumas diretrizes ou regras práticas para enquadrar políticas para o Estado desenvolvimento na atualidade. 
- Ser cauteloso ao aceitar conselhos do Banco Mundial e de outras agências ocidentais sobre política industrial, tal como essa declaração da alta administração do Banco Mundial para sua Diretoria Executiva, em 1991:"Mesmo que as causas do fracasso do governo possam ser identificadas e minimizadas, o relatório apela para o impossível: o ajuste fino de uma série de intervenções comerciais e industriais para lidar com falhas de mercado reais ou percebidas geralmente não é viável ".

- Tal como acontece com a chave para o crescimento sustentado da produtividade, o objetivo é produzir constantemente novos produtos, diferentemente de depender do aprendizado em um conjunto estável de produtos. Para isso, devese apoiar um número relativamente pequeno de setores em qualquer momento. Os empréstimos concessionais, ou incentivos ao investimento fiscal, podem ser direcionados para a produção de novos produtos ou produtos já na fronteira de desempenho do país. À medida que mais produtores se tornarem capazes de atender aos padrões de produtividade, deve-se ajustar os alvos para cima (Wade, 1990/2004: Apêndice A).

- Pensar em promover as exportações e substituir as importações não como alternativas, mas como complementos ("duas asas da mesma ave"). Esquemas como os duty drawbacks podem ser usados para proteger os exportadores das importações (Wade, 1991).

- Usar proteção não para isolar os produtores domésticos da pressão competitiva internacional, mas para protegê-los - por exemplo, limitando a proteção a um determinado período dentro do qual os produtores protegidos devem chegar perto do preço e da qualidade dos substitutos importados (Wade, 1993).

- Atuar estrategicamente ao atrair porções selecionadas de CVGs para o território nacional. O governo pode barganhar duramente com uma corporação multinacional de modo a maximizar a transferência de habilidades para os cidadãos (ou pode deixar a corporação decidir por si mesma quantos cidadãos empregar em quais estágios de quais operações). Ao longo da rápida fase de catchup, os governos sul-coreanos e taiwaneses negociavam com as multinacionais, de forma que os governos de muitos outros países em desenvolvimento (Chile e Hong Kong, por exemplo) não fizeram ${ }^{10}$. Na atualidade, barganhar duro com as empresas chinesas é especialmente importante, porque o seu financiamento é muitas vezes obscuro e eles normalmente desejam transferir pouco conhecimento para os locais (Larmer, 2017).

- Os países de renda média não devem depender de investimento estrangeiro direto combinado com baixos salários. Para ter uma perspectiva séria de escapar da armadilha de renda média, os países têm que investir pesadamente na capacidade doméstica de inovar, indo além da imitação e além da vantagem comparativa. Isso significa investir em ciência e engenharia, P\&D e aproveitar a diáspora altamente qualificada do país. 
- Proteger a economia contra os efeitos anti-catch-up da financeirização. Se as oportunidades de lucros financeiros (por exemplo, nos setores de FIRE) não forem contidas, o Estado terá dificuldade em orientar as empresas privadas para atividades socialmente produtivas. Enfrentar essas oportunidades significa regular os fluxos de capital (o governo dos EUA se opõe fortemente a seus parceiros nos acordos comerciais e ao qual o FMI e o Banco Mundial também se opõem).

- Gerenciar a taxa de câmbio de modo a conter os efeitos de backwash na formação de uma taxa de câmbio supervalorizada pelas exportações de commodities.

- Prestar atenção em como os EUA evadem ao dizer ao resto do mundo para não praticar a política industrial, enquanto implementam uma política industrial eficaz (mais precisamente, política de inovação). O modo predominante de governança econômica dos EUA é próximo do neoliberal (com menos insistência na competição e mais tolerância ao oligopólio), mas há muito tempo tem um Estado de desenvolvimento oculto por trás da cultura e das instituições neoliberais. Esse Estado desenvolvimentista toma a forma de agências piloto descentralizadas em nível federal e estadual para promover o progresso tecnológico em setores selecionados que, por razões políticas, mantêm suas atividades fora do radar (belowthe radar) (Wade, 2017b) ${ }^{11}$.

\section{CONCLUSÃO}

O teto de vidro na economia mundial pode ter se tornado ainda mais forte nas últimas duas décadas, devido a certas forças globais que reforçam a estrutura centroperiferia através da qual as CDs precisam manobrar quando se integram à economia mundial: (a) financeirização; os centros de finanças ainda predominam no Ocidente, o dólar ainda é a moeda internacional dominante e há pressão sobre os DCs para abrir suas contas de capital; (b) cadeias globais de valor, com poder de mercado altamente concentrado em empresas baseadas principalmente no Ocidente e no Japão; (c) monopólio de propriedade intelectual, também baseado principalmente no Ocidente; e (d) pressão sobre os países deficitários para reduzir os déficits na ausência de pressão sobre os países superavitários para gastar seus excedentes.

Tendo em conta os elementos apontados, enfatizei uma força global que opera no nível das idéias cognitivas e normativas apoiadas pela poderosa agência ocidental: a economia neoliberal e seu endosso a um papel do Estado regulador do mercado, sua profunda hostilidade a qualquer coisa próxima de um Estado desenvolvimentista e para qualquer coisa chamada política industrial. Os países anglo-saxões (os EUA, o Reino Unido e a Alemanha) têm sido o cockpit global da economia neoliberal. Não coincidentemente, os dois primeiros foram os dois únicos Estados hegemônicos do mundo nos últimos dois séculos e o terceiro foi durante décadas um aspirante hegemônico. A economia neoliberal aplicada de forma abrangente pelo núcleo da 
periferia é uma receita eficaz para preservar a estrutura centro-periferia da economia mundial; para chutar a escada, na colorida metáfora de Friedrich List.

Os casos notáveis de países não ocidentais que romperam o teto de vidro tiveram em comum um Estado desenvolvimentista implementando uma estratégia de transformação industrial ao longo de décadas, indo muito além das prescrições da economia neoliberal. Suas "intervenções" são dirigidas pelo entendimento de que "o mercado", deixado sem orientação, está propenso a falhas de coordenação e é improvável que explore os retornos crescentes de escala e as economias externas cruciais para o processo de crescimento. O mercado não guiado perderá muito do valor dos benefícios que uma nova empresa ou indústria pode conceder aos outros. E perderá os efeitos potencialmente devastadores nos países mais pobres do livre comércio, movimentos de capital e migração com os países ricos. Um Estado desenvolvimentista, exercendo a visão de toda a economia de uma forma que nenhuma empresa normalmente faz e gerenciando ativamente as relações externas da economia, pode orientar a estrutura de produção e consumo de modo a capturar os benefícios de crescimento de retornos crescentes de escala e economias externas. No entanto, deve fazê-lo com condições de desempenho associadas à proteção, para contrariar a tendência das empresas de pressionar por subsídios e proteção, a fim de compensar indefinidamente seu déficit de competitividade. É claro que agir como um Estado desenvolvimentista não é fácil; mas podemos estar bastante certos de que um Estado que segue os princípios neoliberais achará muito difícil sustentar o crescimento ao longo de muitas décadas, devido aos fortes efeitos de refluxo vindos da economia mundial, efeitos não vistos pelos defensores neoliberais citados anteriormente.

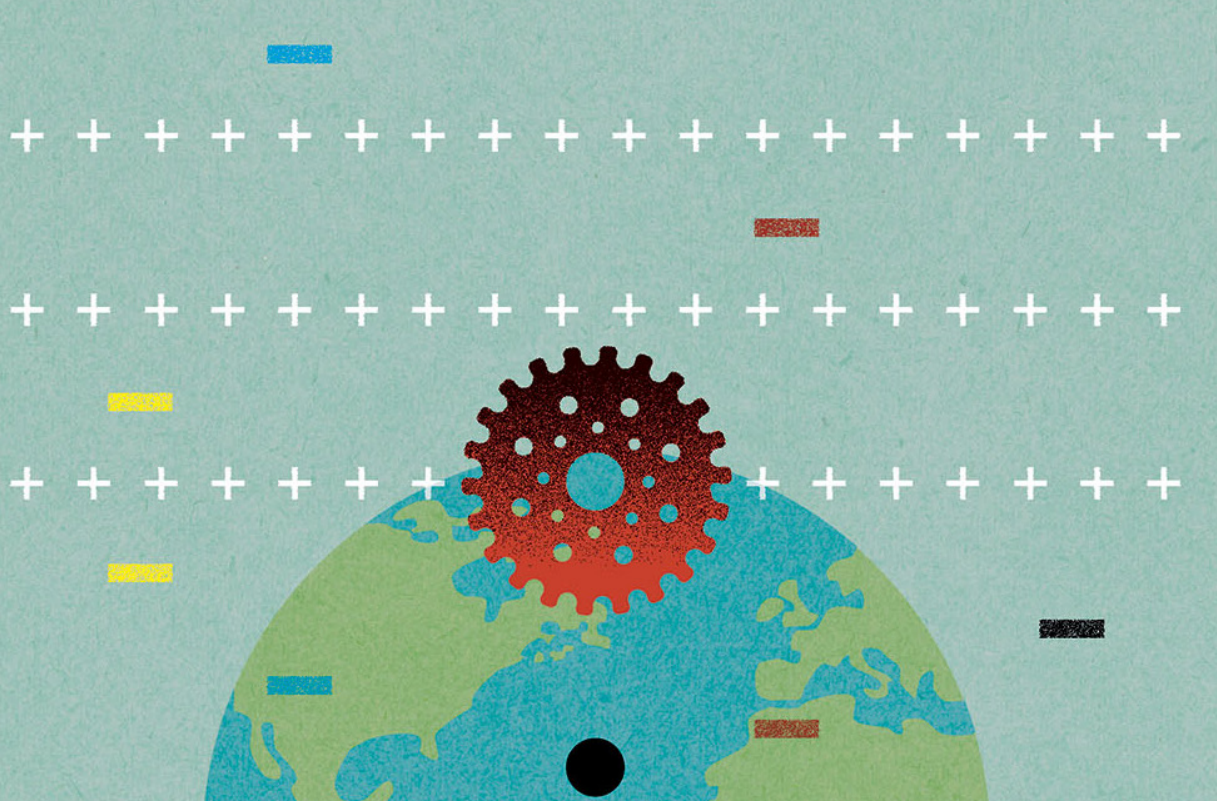


Para terminar, apresento quatro questões. Primeiro, por que os governos de países em desenvolvimento estão dispostos a assinar acordos de comércio e investimento com governos de países desenvolvidos que restrinjam muito seu espaço político (incluindo permitir as regras da OMC?). Fazendo isso, estão desistindo de espaço político, muitas vezes em troca de muito pouco (por exemplo, melhor acesso ao mercado do países desenvolvido para commodities não processadas). Sua escolha ajuda a proteger a estrutura hierárquica da economia mundial. Em segundo lugar, na medida em que os países ou regiões individuais utilizam espaço político, temos mais fragmentação no regime de governança global. A questão então é como instituir «sistemas de tráfego» entre os conjuntos de regras mais diversificados, de modo a reduzir os custos de transação sem que todos tenham que jogar pelas mesmas regras? Terceiro, a China usará sua crescente influência na governança econômica global para pressionar por mais espaço político nas regras globais e regionais, de acordo com o que realmente fez; ou vai começar a se comportar como um país central e apoiar uma agenda do Consenso de Washington com outro nome? E, em quarto lugar, como lidaremos com os problemas gerados no nível da economia global, como os efeitos desestabilizadores de fazer com que os países com déficits em conta corrente cortem seus déficits, ao mesmo tempo em que deixam os países com superávit sem pressão para reduzir seus superávits? É claro que os EUA, com seu dólar conferindo um "privilégio exorbitante", são uma exceção notável à pressão de ajuste assimétrica nos países deficitários.

\footnotetext{
Notas

' Para uma rica discussão do livro do Milagre do Leste Asiático, com comentaristas do Japão, Ásia, Reino Unido e EUA, ver OECF (1995). Também: Rodrik (1994); Wade (1995, 1996).

2 Para uma crítica não-polêmica da economia do desenvolvimento neoliberal, ver Thirlwall e PachecoLopez (2017).

${ }^{3}$ A de meados de 2015, o Banco definiu as economias de rendimento baixo como aquelas com um Rendimento Nacional Bruto per capita de US \$ 1.045 ou menos em 2014; economias de renda média, como aquelas com mais de US \$1.045, mas menos de US \$12.736; economias de renda alta como aquelas com US \$12.736 ou mais. Separou as economias de renda média e média alta em US $\$ 4.125$ (http://data.worldbank.org/news/new-country-classifications-2015). As 13 economias que atingiram alta renda foram Guiné Equatorial, Grécia, Hong Kong, Irlanda, Israel, Japão, Maurício, Portugal, Porto Rico, República da Coréia, Cingapura, Espanha e Taiwan. Veja também Cherif e Hasanov (2015).

${ }^{4}$ Este artigo deixa Hong Kong de lado, porque foi uma colônia britânica por 150 anos, desde 1841 até 1997, exceto pela ocupação japonesa em tempo de guerra. Hong Kong surfou para a prosperidade devido às suas funções como porto de entreposto para a gigante China e o centro do leste asiático para os bancos britânicos, todos sob a proteção do governo britânico. Cingapura foi uma colônia britânica por 144 anos até 1963, quando se juntou à Federação da Malásia. Tornou-se um estado soberano em 1965 quando saiu da federação; Cingapura, portanto, teve 50 anos como um Estado soberano.

${ }^{5}$ Lewis Carroll, Alice through the Looking Glass, Chapter 7.

${ }^{6}$ Wade (1982) faz um relato detalhado da burocracia coreana em ação nos capilares do sistema estatal; Wade (1985) examina a burocracia da Índia e seu sistema de corrupção. Wade (1992b) faz uma comparação entre a organização burocrática Coreia-Índia.

${ }^{7}$ No original, Gestalt shift.
} 


\begin{abstract}
${ }^{8}$ Um outro ponto contextual: entre 1980 e 2015, a participação do investimento fixo no PIB global caiu de cerca de 20\% para menos de 16\% (UNCTAD, 2016).

${ }^{9}$ The report about industrial policy was from the Operations Evaluation Department. It concluded, 'The Bank [should] help governments design appropriate industrial policies by collecting, analysing and disseminating information' (OED, 1991: 54). The OED is accountable to the Executive Board, not to management. The management appealed to the Executive Board not to release the report, in a memo which contained the quoted sentence. The Japanese Executive Director insisted the report be released, and it sank without trace in the rest of the Bank. The story illustrates how long and fiercely the Bank has resisted the idea of a state imparting directional thrust to market forces, which reflects the distribution of power in its governance (see Wade, 1996).

${ }^{10}$ Enos e Park (1988) relatam que na década de 1970, quando os governos da Coréia do Sul, Chile e Hong Kong encomendaram a mesma usina de etileno da Dow Chemicals, os coreanos pressionaram a Dow a empregar mais pessoas nacionais nos vários estágios do projeto; e a proporção de nacionais para empregados regulares da Dow aumentou em cada uma das duas plantas subseqüentes que a Coréia encomendou à Dow. Este caso se encaixa no lema coreano: "Nunca aprendemos nada duas vezes", um lema que ouvi durante meu trabalho de campo na Coréia em 1979 (Wade, 1982).

${ }^{11}$ Para maiores informações sobre recomendações de reformas institucionais e políticas, ver: Rock (2017); Roll (2014); Wade (2003, 2014, 2016, 2017a).
\end{abstract}

\title{
Referências
}

AKUZ, Y. Playing with Fire: Deepening Financial Integration and Changing Vulnerabilities of the Global South. Oxford: Oxford University Press, 2017.

AMSDEN, A. The Rise of 'The Rest'. Challenges to the West from Late-industrializing Economies. Oxford: Oxford University Press, 2001.

BROADBERRY, S. \& J. WALLIS. Shrink Theory: The Nature of Long Run and Short Run Economic Performance'. Nuffield College Oxford, and University of Maryland, 4 April, 2016. Available at:. https://bit.ly/31 Kwbbn.

BUTCHER, T. Blood River. A Journey to Africa's Broken Heart. New York: Vintage Books, 2007.

CHERIF, R. \& F. HASANOV. The Leap of the Tiger: How Malaysia Can Escape the Middle-income Trap.' IMF Working Paper WP/15/131. Washington, DC: International Monetary Fund, 2015.

CHOW, J.T., F. JAUMOTTE, S.G. PARK \& Y.S. ZHANG. Spillovers from Dollar Appreciation. IMF Policy Discussion Paper No. 15/02. Washington, DC: International Monetary Fund, 2015.

DENT, C. (2007) 'The State and Transnational Capital in Adaptive Partnership: Singapore, South Korea and Taiwan', in H.W. Yeung (ed.) Handbook of Research on Asian Businesses, pp. 223-49. Cheltenham and Northampton, MA: Edward Elgar Publishing.

DEYO, F. The Political Economy of the New Asian Industrialization. Ithaca, NY: Cornell University Press, 1987.

DONER, R. and B.R. Schneider (2016) 'The Middle-income Trap: More Politics than Economics', World Politics, v. 68, n. 4, pp. 1-37, 2016.

Druck, P.F., N.E. Magud and R. Mariscal (2015) 'Collateral Damage: Dollar Strength and Emerging Markets' Growth'. IMF Working Paper 15/179. Washington, DC: International Monetary Fund, 2015.

ENOS, J.L. \& W-H. PARK. The Adoption and Diffusion of Imported Technology: The Case of Korea. New York: Croom Helm, 1988.

EVANS, P. Embedded Autonomy: States and Industrial Transformation. Princeton, NJ: Princeton University Press, 1995.

GELINAS, J. Juggernaut Politics: Understanding Predatory Capitalism. London: Zed Books, 2003.

HAGGARD, S. (forthcoming) Developmental States. Cambridge: Cambridge University Press. 
HALIMI, S. Tyranny of the One Per Cent', Le Monde Diplomatique (English edition) 1 May, 2013.

JOHNSON, C. MITI and the Japanese Miracle: The Growth of Industrial Policy, 1925-1975. Stanford, CA: Stanford University Press, 1982.

KARO, E. (forthcoming) 'Mission-oriented Innovation Policies and Bureaucracies in East Asia', in M. Mazzucato and R. Kattel (eds) 'Innovation Policy and Mission-oriented Public Organizations', special section in Industry and Corporate Change.

KOHLI, A. State-directed Development: Political Power and Industrialization in the Global Periphery. Princeton, NJ: Princeton University Press, 2004.

KRUEGER, A. Government Failures. Development', Journal of Economic Perspectives, v. 4, n. 3, pp. 9-23, 1990.

LANE, N. Manufacturing Revolutions. Industrial Policy and Networks in South Korea. Stockholm: Institute for International Economic Studies, 2017.

LARMER, B. Roads to Nowhere but Debt', New York Times (International) 14 September, 2017.

LAZONICK, W. Innovative Business Models and Varieties of Capitalism: Financialization of the US Corporation'. Business History Review, v. 84, n. 4, pp. 675-702, 2010.

LEE, J. The Wages of Containment: The Cold War and the Origins of the Developmental State'. Working Paper, Department of Political Science. Princeton, NJ: Princeton University, 2017.

LEE, Y-S, I. HEO and H. K. The Role of the State as an Inter-scalar Mediator in Globalizing Liquid Crystal Display Industry Development in South Korea'. Review of International Political Economy, v. 21, n. 1, p. 102-29, 2014.

LUEDDE-NEURATH, R. Import Controls and Export-Oriented Development: A Reassessment of the South Korean Case. Boulder, CO: Westview Press, 1986.

METCALF, S. (2017) 'Neoliberalism: The Idea that Swallowed the World', The Guardian 18 August, 2017. Disponível em: . https://bit.ly/31Q7KsM. Acesso em: 20 mar. 2018.

MILBERG, W. and D. WINKLER. Outsourcing Economics: Global Value Chains in Capitalist Development. Cambridge: Cambridge University Press, 2013.

OECF. The World Bank's East Asia Miracle Report: Its Strengths and Limitations. Discussion Paper No. 7. Tokyo: Research Institute of Development Assistance, Overseas Economic Cooperation Fund, 1995.

OED. OED Study of Bank Support of Industrialization in Newly Industrializing Countries. Washington, DC: Operations Evaluation Department, World Bank, 1991.

PAGANO, U. The Crisis of Intellectual Monopoly Capitalism. Cambridge Journal of Economics, v. 38, n. 6, pp. 1409-29, 2014.

PAGANO, U. (forthcoming) 'Knowledge as a Global Common and the Crisis of the Learning Economy', in M. Guzman (ed.) Economic Theory and Public Policies: Joseph Stiglitz and the Teaching of Economics. New York: Columbia University Press.

PIRIE, I. Korea and Taiwan: The Crisis of Investment-led Growth and the End of the Developmental State', Journal of Contemporary Asia, 2017.

PRITCHETT, L. Divergence, Big Time. Journal of Economic Perspectives, v. 11, n. 3, pp. 3-17, 1997.

PRITCHETT, L. \& SUMMERS, L. Asiaphoria Meets Regression to the Mean'. NBER Working Paper No. 20573. Cambridge, MA: National Bureau of Economic Research, 2014.

RIEDEL, J. Economic Development in East Asia: Doing What Comes Naturally?. In: H. Hughes (ed.) Achieving Industrialization in East Asia, pp. 1-38. Cambridge: Cambridge University Press, 1988. 
ROCK, M. Dictators, Democrats, and Development in Southeast Asia. Oxford: Oxford University Press, 2017.

RODRIK, D. King Kong Meets Godzilla: The World Bank and the East Asian Miracle. In: A. Fishlow et al. Miracle or Design? Lessons from the East Asian Experience, pp. 13-51. Washington, DC: Overseas Development Council, 1994.

RODRIK, D. Why We Learn Nothing from Regressing Economic Growth on Policies. Seoul Journal of Economics, v. 25, n. 2, pp. 137-51, 2012.

ROLL, M. (ed.). The Politics of Public Sector Performance: Pockets of Excellence in Developing Countries. London and New York: Routledge, 2014.

SATO, H. The Rise and Fall of the Developmental State? The Case of the Japanese and South Korean Steel Industries. In: B. Fine, J. Saraswati and D. Tavasci (eds) Beyond the Developmental State: Industrial Policy into the Twenty-first Century, pp. 33-60. London: Pluto Press, 2013.

STARRS, S. (The Chimera of Global Convergence. New Left Review 87 (May/June), pp. 81-96, 2014.

THIRLWALL, A. \& P. PACHECO-LOPEZ (2017) Economics of Development (10 th edn). Basingstoke: Palgrave Macmillan, 2017.

THURBON, E. The Resurgence of the Developmental State: A Conceptual Defence. Critique Internationale 2(63): 1-16, 2014.

THURBON, E. Developmental Mindset: The Revival of Financial Activism in South Korea. Ithaca, NY: Cornell University Press, 2016.

UCHITELLE, L. Challenging the Dogmas of Free Trade', New York Times 9 February, 2002. Disponível em: https://nyti.ms/2Vb0qFT.

UNCTAD. Trade and Development Report: Structural Transformation for Inclusive and Sustained Growth. Geneva: United Nations Conference on Trade and Development, 2016.

VITALI, S. and S. BATTISTON (2014) 'The Community Structure of the Global Corporate Network', PLoS ONE 9(8), 2014 (online

WADE, R. Irrigation and Agricultural Politics in South Korea. Boulder, CO:Westview Press, 1982.

WADE, R. The Market for Public Office: Why the Indian State Is Not Better at Development. World Development, v. 13, n. 4, pp. 467-97, 1985.

WADE, R. Industrial Policy in East Asia: Does it Lead or Follow the Market?. In: G. Gereffi and D.L. Wyman (eds) Manufacturing Miracles: Paths of Industrialization in Latin America and East Asia, pp. 231-66. Princeton, NJ: Princeton University Press.

WADE, R. (1990/2004) Governing the Market. Princeton, NJ: Princeton University Press.

WADE, R. How to Protect Exports from Protection: Taiwan's Duty Drawback Scheme. The World Economy, v. 14, n. 3, pp. 299-309, 1991.

WADE, R. East Asian Economic Success: Conflicting Paradigms, Partial Insights, Shaky Evidence', World Politics, v. 44, n. 2, pp. 270-320, 1992a.

WADE, R. How to Make "Street Level" Bureaucracies Work Better: India and Korea', IDS Bulletin, v. 23, n. 4, pp. 51-54, 1992b.

WADE, R. Managing Trade: Taiwan and South Korea as a Challenge to Economics and Political Science. Comparative Politics, v. 25, n. 2, pp. 147-67, 1993.

WADE, R. Qualifications to the Economics of The East Asia Miracle Book. In: OECF 'The World Bank's East Asia Miracle Report: Its Strengths and Limitations', pp. 108-13. Discussion Paper No. 7. Tokyo: Research Institute of Development Assistance, Overseas Economic Cooperation Fund, 1995. 
WADE, R. Japan, the World Bank, and the Art of Paradigm Maintenance: The East Asian Miraclein Political Perspective. New Left Review 217, pp. 3-36, 1996.

WADE, R. What Strategies Are Viable for Developing Countries Today? The World Trade Organization and the Shrinking of "Development Space'. Review of International Political Economy, v. 10, n. 4, pp. 621-44, 2003.

WADE, R. Greece, Breaking the Doom Loop. Le Monde Diplomatique (English edition) 6 July.

WADE, R. Market versus State" or "Market with State: How to Impart Directional Thrust'. Development and Change, v. 45, n. 4, pp. 777-98, 2014.

WADE, R. Agenda Change in Western Development Organizations: From Hard Production to Soft, Timeless, Placeless Policy. Lahore Journal of Economics 20(SE): 1-12, 2015.

WADE, R. Industrial Policy in Response to the Middle-income Trap and the Third Wave of the Digital Revolution. Global Policy, v. 7, n. 4, pp. 465-585, 2016.

WADE, R. Is Trump Wrong about Trade? A Partial Defense, based on Production and Employment. In: E. Fullbrook and J. Morgan (eds) Trumponomics: Causes and Consequences, pp. 1-35. London: College Publications, 2017a.

WADE, R. The American Paradox: Ideology of Free Markets and Hidden Practice of Directional Thrust. Cambridge Journal of Economics, v. 41, n. 3, pp. 859-80, 2017b.

WEISS, L. The Myth of the Powerless State. Ithaca, NY: Cornell University Press, 1998. 